\title{
The use of chickpea flour in the minced meat products formula
}

\author{
Amina Dzhaboeva ${ }^{1,{ }^{*}}$, Olesya Byazrova $^{2}$, Victoria Tedtova $^{2}$, Zarina $_{\text {Baeva }}{ }^{2}$, and Marina \\ Kokaeva $^{2}$ \\ ${ }^{1}$ Kabardino-Balkarian State Agricultural University named after V.M. Kokov, Lenin Avenue, 1V, \\ 360030 Nalchik, Russia \\ ${ }^{2}$ North Caucasian Mining and Metallurgical Institute (State Technological University), Nikolaeva 44, \\ 362021 Vladikavkaz, Russia
}

\begin{abstract}
The goal of the research was to substantiate the possibility of using various doses of chickpea flour in the recipe for the "Chopped Beefsteak" instead of beef to improve its consumer and protective properties. Taking into account the functional and technological properties and organoleptic characteristics of various minced meat models, the most optimal dose of including chopped chickpea flour in the formulation of semi-finished steak is $5.0 \%$ to the mass of minced meat. To assess the consumer qualities of the compared samples of the "Chopped beefsteak" dish with the addition of chickpea flour in a dosage of $5 \%$ to the mass of minced meat, technological charts were drawn up on the basis of recipe No. 604. When chickpea flour was included in the amount of $5.0 \%$ to the mass of minced meat, the consumer characteristics of the finished product were improved. Was found, that chickpea flour is a valuable dietary product, it is distinguished by high taste and health characteristics.
\end{abstract}

\section{Introduction}

It is known that in the modern domestic food market, the range of sold frozen semi-finished products from meat of different types of domestic and wild animals plays a very significant role in various regions of our country and is of great importance. One of the main valuebased consumer benefits of this category of food and semi-finished products sold through the distribution network and public catering enterprises is a significant reduction in the preparation and duration of their preparation for consumption [1, 2, 3, 4].

At present, due to the presence of the facts of environmental pollution due to anthropogenic nature and an increase in the number of ecologically caused manifestations of various types of diseases, the prospect of creating plant groups of food plant additives that have antitoxic and protective actions on biological processes in the body is of particular importance and relevance. Extremely relevant interest in the domestic market is paid to the search for food additives that are of natural origin and have detoxifying and adsorbing properties. Moreover, they, unlike chemical preparations, should not cause numerous side effects on the physiological and biochemical state of consumers $[5,6,7,8]$.

\footnotetext{
* Corresponding author: kapmar17@gmail.com
} 
Of all legumes, chickpeas are considered the leader in terms of nutrient content. It is a unique natural plant source of biogenic nutrients (proteins and amino acids, simple carbohydrates, easily and indigestible polysaccharides (including dietary fiber), lipids, vitamins of different groups, macro- and microelements), which are contained in optimal proportions. Due to the presence of a significant amount of fibrous polysaccharides (fiber) in chickpea flour, which are necessary for the consumer's body as natural enterosorbents for all types of xenobiotics, the functional activity of most body systems is optimized. The presence in the composition of food of coarse plant fibers contributes to the improvement of digestion and promotes the detoxification of various toxic substances, including heavy metals $[9,10,11,12]$.

The goal of the research was to substantiate the possibility of using various doses of chickpea flour in the recipe for the "Chopped Beefsteak" instead of beef to improve its consumer and protective properties.

\section{Materials and Methods}

To achieve this goal under conditions, an experiment was conducted to study the effectiveness of the inclusion of chickpea flour in the recipe for the "Chopped beefsteak" dish.

We took as the objects of our research:

- chopped semi-finished meat products (steaks) prepared according to traditional technology and recipes and with the addition of different amounts of chickpea flour.

- chickpea flour (besan) gluten free. We used chickpea flour "Vkusnoe Delo" produced by AltaiBio LLC ( Barnaul) Altai Territory, Russian Federation

In this regard, according to the results of the research carried out, we proposed a method for optimizing the recipe for minced meat products by adding chickpea flour, which includes 4 stages of metroprocessing:

- at the first stage - the substantiation of the preparation of minced meat dishes, that is, the "Chopped beefsteak" dish, was carried out;

- at the second stage - formulations and the choice of technology for preparing beefsteak samples using chickpea flour were developed. At the same time, the optimal dose of introducing chickpea flour into the recipe of the studied dish was established;

at the third stage - a comparative merchandising and detoxification assessment of the compared steak samples was carried out;

- at the IV stage - a scientific, practical and economic substantiation of the inclusion of the best dose of chickpea flour in the recipe for the "Chopped beefsteak" dish was completed.

In the course of the research, steaks prepared according to the current recipe served as a control sample, and in the composition of 3 prototypes of finished products, 3,5 and $7 \%$ of the mass of raw materials were replaced with chickpea flour.

\section{Research results and discussion}

Consumer properties of chickpea flour are primarily due to its chemical composition. Indicators characterizing the chemical composition and energy value of Desi chickpea flour are presented in Table 1 . 
Table 1. Indicators of the chemical composition and energy value of chickpea flour

\begin{tabular}{|l|c|}
\hline \multicolumn{1}{|c|}{ Indicator } & Indicator value \\
\hline Mass fraction of dry substances, $\mathrm{g} / 100 \mathrm{~g}$ & 86.0 \\
\hline Mass fraction of proteins, $\mathrm{g} / 100 \mathrm{~g}$ & 22.0 \\
\hline Mass fraction of lipids, $\mathrm{g} / 100 \mathrm{~g}$ & 6.0 \\
\hline Nitrogen-free extractive substances, $\mathrm{g} / 100 \mathrm{~g}$ & 46.0 \\
\hline Mass fraction of fiber, $\mathrm{g} / 100 \mathrm{~g}$ & 11.0 \\
\hline Mass fraction of minerals, $\mathrm{g} / 100 \mathrm{~g}$ & 1.0 \\
\hline Energy value of $100 \mathrm{~g}$ of product, $\mathrm{kcal}$ & 387 \\
\hline Vitamins, incl. & \\
\hline fat soluble: & 3.0 \\
\hline $\mathrm{A}, \mu \mathrm{g} / 100 \mathrm{~g}$ & 0.8 \\
\hline $\mathrm{E}, \mathrm{mg} / 100 \mathrm{~g}$ & \\
\hline water soluble: & 6.0 \\
\hline $\mathrm{C}_{\mathrm{g}} \mathrm{mg} / 100 \mathrm{~g}$ & 1.6 \\
\hline $\mathrm{PP}, \mathrm{mg} / 100 \mathrm{~g}$ & 0.5 \\
\hline $\mathrm{B}_{1}, \mathrm{mg} / 100 \mathrm{~g}$ & 0.2 \\
\hline $\mathrm{B}_{2}, \mathrm{mg} / 100 \mathrm{~g}$ & 1.0 \\
\hline $\mathrm{B}_{5}, \mathrm{mg} / 100 \mathrm{~g}$ & 0.5 \\
\hline $\mathrm{B}_{6}, \mathrm{mg} / 100 \mathrm{~g}$ & 557.0 \\
\hline $\mathrm{B}_{9}, \mu \mathrm{g} / 100 \mathrm{~g}$ & \\
\hline
\end{tabular}

As can be seen from the data in Table 1, the water content in chickpea flour was $14.0 \%$ and dry matter $-86.0 \%$, which indicates its good preservation for a long time, since with a similar amount of moisture in the product, mold mycoflora develops extremely slowly

A distinctive feature of chickpeas is the high content of structured carbohydrates - fiber (up to $11.0 \%$ ). This factor contributes to the enhancement of intestinal motility. In addition, fiber in the gastrointestinal tract binds various toxic compounds and removes them from the body. Therefore, the addition of chickpea flour to the formulation of various products and dishes makes it possible to improve their protective qualities.

The energy value of $100 \mathrm{~g}$ of chickpea flour is $387 \mathrm{kcal}$, which makes it a high-value food additive.

Chickpea flour is rich in vitamins, including B vitamins, fat-soluble A and E. Particular attention should be paid to the high concentration of antioxidant and hypoxant vitamin $\mathrm{C}$ up to $6.0 \mathrm{mg} / 100 \mathrm{~g}$ of chickpea flour, which indicates a high dexication capacity of this product.

When evaluating the best dosage for the inclusion of chickpea flour in the recipe for the "Chopped beefsteak" dish, we studied the chemical composition of semi-finished products (table. 2)

The control sample of the semi-finished product without the use of chickpea flour additives had the highest rates of moisture binding and water retention capacity. In addition, with an increase in the dose of the inclusion of flour from chickpea in the minced meat products formula due to the increased presence of fibre, an inverse relationship with the value of indicators characterizing the water-binding power and water-retaining power was observed. The consequence of this was a decrease in the structural and mechanical characteristics of prototypes of semi-finished products. 
Table 2. The chemical composition of semi-finished steak

\begin{tabular}{|l|c|c|c|c|}
\hline \multirow{2}{*}{\multicolumn{1}{|c|}{ Indicator }} & \multicolumn{4}{c|}{ Indicator value } \\
\cline { 2 - 5 } & control & $\begin{array}{c}\text { experienced } \\
\text { sample No. 1 }\end{array}$ & $\begin{array}{c}\text { experienced } \\
\text { sample No. 2 }\end{array}$ & $\begin{array}{c}\text { experienced } \\
\text { sample no. 3 }\end{array}$ \\
\hline Mass fraction of water, g/100 g & 56.7 & 55.2 & 54.7 & 54.1 \\
\hline Mass fraction of proteins, g/100 g & 27.2 & 27.7 & 27.9 & 28.2 \\
\hline Mass fraction of lipids, g/100 g & 15.0 & 14.9 & 14.6 & 14.4 \\
\hline $\begin{array}{l}\text { Mass fraction of carbohydrates, rg100 } \\
\mathrm{g}\end{array}$ & - & 1.3 & 1.9 & 2.5 \\
\hline$\quad$ incl. fiber, g/100 g & - & 0.45 & 0.65 & 0.85 \\
\hline Mass fraction of ash, g/100 g & 0.96 & 0.94 & 0.93 & 0.92 \\
\hline Energy value, kcal & 253 & 252 & 252 & 252 \\
\hline
\end{tabular}

With an increase in the dose of chickpea flour additives from 3 to $7 \%$ in the composition of chopped steak in relation to the control sample, there was a tendency to a decrease in the mass fraction of water, fat, ash and calorie content with a simultaneous increase in the mass fraction of protein, carbohydrates, including fiber. This indicates an increase in the consumer and protective properties of the prototypes.

To establish the optimal dosage for the introduction of chickpea flour instead of a part of beef meat in the recipe for semi-finished steak products, it was necessary to study the effect of different dosages of the food additive on the water-binding power and waterretaining power (table. 3 )

Table 3. Structural and mechanical characteristics of steaks

\begin{tabular}{|l|c|c|}
\hline \multirow{2}{*}{$\begin{array}{c}\text { Name of } \\
\text { sample }\end{array}$} & \multicolumn{2}{|c|}{ Indicator name } \\
\cline { 2 - 3 } & water-binding power, \% & $\begin{array}{c}\text { water-binding } \\
\text { power, \% }\end{array}$ \\
\hline Control & 90.7 & 67.8 \\
\hline 1 test & 89.4 & 65.5 \\
\hline 2 test & 87.6 & 63.9 \\
\hline 3 test & 85.8 & 62.3 \\
\hline
\end{tabular}

Consequently, as a result of the studies carried out, taking into account the obtained functional and technological properties and sensory indicators of various minced model products, the optimal dosage of chickpea flour in the minced steak recipe is $5.0 \%$ to the mass of minced meat.

Technological maps of the control and experimental samples are presented in tables 4 and 5.

Table 4. Technological map number 1. Recipe No. 604 (II column) Chopped steak (control sample)

\begin{tabular}{|l|c|}
\hline \multicolumn{1}{|c|}{ Raw materials } & Net, $\mathrm{g}$ \\
\hline Beef & 80 \\
Pork fat & 12 \\
Milk & 6.76 \\
Ground black pepper & 0.04 \\
Salt & 1.2 \\
Semi-finished product weight & 100 \\
Melted edible animal fat & 7 \\
Fried product weight & 70 \\
\hline
\end{tabular}


Table 5. Technological map number 2. Recipe No. 604 (II column) Chopped steak (prototype)

\begin{tabular}{|l|c|}
\hline \multicolumn{1}{|c|}{ Raw materials } & Net, $\mathrm{g}$ \\
\hline Beef & 75 \\
Chickpea flour & 5 \\
Pork fat & 12 \\
Milk & 6.76 \\
Ground black pepper & 0.04 \\
Salt & 1.2 \\
Semi-finished product weight & 100 \\
Melted edible animal fat & 7 \\
Fried product weight & 70 \\
\hline
\end{tabular}

After the preparation of the compared samples of the chopped steak by the tasting commission of the Department of Technology of Public Food Products of the North Caucasus Mining and Metallurgical Institute (State Technological University) consisting of 7 people, their organoleptic assessment was carried out (table. 6)

Table 6. Organoleptic evaluation of the compared samples of the "Chopped beefsteak" dish, score

\begin{tabular}{|l|c|c|}
\hline \multirow{2}{*}{ Indicator name } & \multicolumn{2}{c|}{ sample } \\
\cline { 2 - 3 } & control & experienced \\
\hline Appearance & $8,14 \pm 0,11$ & $8,20 \pm 0,11$ \\
Sectional color & $7,50 \pm 0,14$ & $8,05 \pm 0,15$ \\
Taste & $8,02 \pm 0,12$ & $8,29 \pm 0,13$ \\
Smell & $7,81 \pm 0,15$ & $8,18 \pm 0,17$ \\
Texture & $7,65 \pm 0,14$ & $7,51 \pm 0,14$ \\
Juiciness & $7,81 \pm 0,15$ & $7,69 \pm 0,12$ \\
\hline Total score & $46,93 \pm 0,14$ & $47,92 \pm 0,15$ \\
\hline
\end{tabular}

Products prepared with chickpea flour had an inversely proportional relationship with indicators of juiciness and consistency, therefore, according to these indicators, the experimental sample was inferior to the control one, which is associated with lower parameters of the moisture-binding and water-holding capacity of their minced meat due to an increase in the concentration of fiber.

The developed steak outperformed the control sample by 0.99 points in terms of the total quality score.

Therefore, to increase the consumer properties of the "Chopped beefsteak" dish, chickpea flour should be added to its recipe in an amount of $5.0 \%$ to the mass of minced meat instead of beef.

According to the methodology for assessing the detoxification properties of meat products on laboratory rats of the "Wistar" line, divided according to the principle of analogues into control and experimental groups, numbering 5 individuals, an experiment was carried out within 10 days.

Animals of the compared groups received lead sulfate $\left(\mathrm{PbSO}_{4}\right)$ in the diet at a dosage of $10 \mathrm{mg} / \mathrm{kg}$ feed. Along with this, rats from the control group consumed beefsteak prepared without chickpea flour. The animals of the experimental group were introduced into the diet of a steak with a $5.0 \%$ dosage of chickpea flour.

The results of the analysis of blood samples of laboratory animals in the compared groups are shown in Table 7.

Table7. Factor for determining the level of lead in the blood of experimental animals

\begin{tabular}{|c|c|c|c|}
\hline \multirow{2}{*}{$\begin{array}{c}\text { Group of rats for } \\
\text { and Analytical Research } \\
\text { Department }\end{array}$} & \multirow[b]{2}{*}{$\begin{array}{l}\text { MAC } \\
\mathrm{mg} / \mathrm{kg}\end{array}$} & \multicolumn{2}{|c|}{ Lead content in rats in blood, $\mathrm{mg} / \mathrm{kg}$} \\
\hline & & $\begin{array}{c}\text { at the beginning of } \\
\text { the experiment }\end{array}$ & $\begin{array}{l}\text { at the end of the } \\
\text { experiment }\end{array}$ \\
\hline Control & 0.12 & $0,068 \pm 0,003$ & $0,136 \pm 0,003$ \\
\hline Test & 0.12 & $0,069 \pm 0,002$ & $0,080 \pm 0,003$ \\
\hline
\end{tabular}


By the end of the experiment, the level of lead in the blood of laboratory rats from the control group had doubled and exceeded the MAC. Against animals from the control group, by the end of the experiment, the content of lead in the blood of rat pups in the experimental group was significantly ( $\mathrm{P}>0.95)$ lower by $41.17 \%$. Moreover, its concentration in their blood did not exceed the MAC.

Therefore, the addition of chickpea flour to the recipe of the "Chopped Beefsteak" dish in the amount of $5.0 \%$ to the mass of minced meat increases its detoxifying properties. In addition, the developed steak is enriched with fiber and differs from the traditional product in a pleasant "nutty" taste and aroma, which has a positive effect on the consumer characteristics of the finished product.

\section{Conclusions}

1. A distinctive feature of chickpea flour is a high content of structured carbohydrates fiber (up to $11.0 \%$ ), which binds various toxic compounds in the gastrointestinal tract and removes them from the body. Particular attention should be paid to the high concentration of antioxidant and hypoxant vitamin $\mathrm{C}$ in chickpea flour (up to $6.0 \mathrm{mg} / 100 \mathrm{~g}$ ), which indicates a high detoxifying ability of the product. The presence of chickpea flour in minced meat recipes led to an increase in fiber content. It was found that with an increase in the dosage of flour from chickpea in the minced meat system, the values of the waterbinding power and water-retaining power indexes decrease, which reduces the adhesion properties of the particles of the dispersed phase.

2. Considering the functional and technological properties and organoleptic characteristics of various minced meat models, the optimal dosage of chickpea flour, at which a quality-improving effect is achieved, is $5.0 \%$ to the mass of minced meat. To assess the consumer qualities of the compared samples of the "Chopped beefsteak" dish with chickpea flour in the amount of $5 \%$ to the mass of minced meat based on recipe No. 604 of the Collection of recipes for dishes and culinary products for public catering enterprises, technological documentation has been developed.

3. With the introduction of $5.0 \%$ chickpea flour into the minced beef steak recipe instead of a part of beef meat, an improvement in organoleptic parameters was observed. It was revealed that chickpea flour is a valuable dietary product, characterized by high taste and health benefits.

4. It was found that the addition of chickpea flour to chopped beefsteak significantly reduces the lead content in the blood of rat pups from the experimental group, whose diet was supplemented with lead sulfate $\left(\mathrm{PbSO}_{4}\right)$ at a dosage of $10 \mathrm{mg} / \mathrm{kg}$ of feed, which indicates high detoxification properties of the processed product.

\section{References}

1. S. F. Sukhanova, S. I. Kononenko, R. V. Temiraev, T. T. Tarchokov, Z. T. Baeva, L. A. Bobyleva, B. M. Shipshev, Journal of Pharmaceutical Sciences and Research, 10(11), 2969-2971 (2018)

2. V. V. Tedtova, Yu. A. Yuldashbaev, A. S. Dzhaboeva, V. R. Kairov, D. A. Yurin, Z. T. Baeva, A. A. Baeva, M. K Kozhokov, A. V. Khmelevskaya, Journal of Livestock Science, 10(1), 109-113 (2019)

3. I. R. Tlitseruk, F. N. Tsogoeva, S.V. Olisaev, T. A. Revazov, Bulletin of Maykop State Technological University, 3, 34-37 (2011)

4. V.K. Temiraev, V.R. Kairov, R.V. Kalagova, Biology and Medicine, 6(3), BM-046-14. (2014) 
5. V. A. Pogodaev, A. N. Arilov, A. F. Shevhuzhev, A. P. Marynich, R. H. Kochkarov, Research Journal of Pharmaceutical, Biological and Chemical Sciences, 8(1), 10861090 (2017)

6. V. V. Tedtova, Z. T. Baeva, E. S. Dzodzieva, Z. Ya. Tsopanova, A. H. Pilov, Meat Industry, 3, 60-62 (2013)

7. Y. A. Yuldashbaev, R. V. Temiraev, V. V. Tedtova, K. V. Temiraev, R. V. Osikina, M. S. Gazzaeva, L. H. Shugusheva, I. K Sattsaeva, M. M. Udychak, Journal of Livestock Science, 11(8-13) (2020)

8. D. S. Shkhalakhov, A. A. Nesterenko, Young Scientist, 23, 109-111 (2016)

9. S.A. Gordynets, V. S. Vetrov, L. P. Shalumkova, Meat Industry, 11, 44-46 (2004)

10. L. V. Antipova, A. A. Archipenko, A. L. Kulpina, Bulletin of the Russian Agricultural Academy, 4, 73-74 (1998)

11. K. Yu. Shebela, N. Yu. Sarbatova, Innovative Science, 2-5(5), 149-152 (2015)

12. G. P. Maltsev, M. M. Sadulaev, N. M. Sivolobova A. L. Semenov, Food ingredients. Raw materials and additives, 8, 73-74 (2003) 